\title{
PROGRAM PENGABDIAN MASYARAKAT: ALAT BANTU BELAJAR ILMU BATUAN BERBASIS ANDROID PADA KELAS GEOLOGI TAMBANG SMK NEGERI 1 SENDAWAR
}

\author{
Joli Afriany"), Reza Andrea ${ }^{2)}$, Ekawati Yulsilviana ${ }^{3)}$, Sefty Wijayanti ${ }^{4)}$, dan Daniel Nabile ${ }^{5)}$ \\ ${ }^{1}$ Universitas Nahdatul Ulama Sumatera Utara \\ ${ }^{2}$ Teknik Informatika, STMIK Widya Cipta Dharma \\ ${ }^{3,4,5}$ Manajemen Informatika, STMIK Widya Cipta Dharma \\ ${ }^{1}$ Jl. H. A. Manaf Lubis No.2 Helvetia, Medan, 20153 \\ 2,3,4,5 Jl. M. Yamin No.25, Samarinda, 75123 \\ E-Mail : joliafriani@gmail.com ${ }^{1)}$, reza@wicida.ac.id ${ }^{2}$, ekawicida@gmail.com ${ }^{3)}$, seftywicid@gmail.com ${ }^{4}$, \\ danielnabile@gmail.com ${ }^{5)}$
}

\begin{abstract}
ABSTRAK
Pembelajaran berbasis multimedia adalah pembelajaran yang dalam proses pembelajarannya menggunakan media aplikasi multimedia dengan tujuan untuk menyalurkan pesan pengetahuan, pengetahuan dan sikap serta dapat merangsang pikiran, perasaan perhatian dan kemauan untuk belajar. SMK Negeri 1 Sendawar sekolah kejuruan dengan program keahlian jurusannya adalah Geologi Tambang. Dalam hal media penyampaian ke peserta didik digunakan buku-buku yang berhubungan langsung dengan ilmu batuan namun kadang kala siswa/i tidak memahami secara detail materi yang disampaikan sehingga pada pada tingkat yang lebih tinggi siswa terkadang harus mengulang dari awal memahami materi tentang ilmu batuan.

Kegiatan pengabdian pengembangan alat belajar ini dibuat dengan dua tahap yaitu desain program menggunakan software Swishmax 4 dan Eclipse Indigo sebagai converter menjadi .apk. Tahapan kegiatan pengumpulan data untuk pengembangan aplikasi ini menggunakan metode observasi, wawancara dan studi pustaka. Berdasarkan hasil kegiatan pengabdian yang telah dilakukan diperoleh kesimpulan bahwa alat bantu belajar ilmu batuan berbasis android ini telah berhasil dibuat dan membantu pembelajaran di kelas geologi tambang.
\end{abstract}

Kata Kunci: Pengabdian, Alat Bantu Ajar, Ilmu Batuan, Geologi, Android.

\section{PENDAHULUAN}

Ilmu Batuan adalah salah satu materi pelajaran dalam bidang jurusan geologi tambang. Di dalam materi ilmu batuan terdapat 3 materi utama yaitu mengenai ganesa batuan atau sejarah terbentuknya batuan. Dalam ganesa batuan terbagi menjadi 3 jenis yaitu : ganesa batuan sedimen, batuan beku dan batuan metamorf.

Di dalam mempelajari 3 materi utama tersebut terkadang siswa kesulitan untuk memahami perbedaan dari ke tiga jenis ganesa batuan tersebut sehingga pada tingkatan yang lebih tinggi siswa harus mengulang kembali materi tersebut.

Untuk mengatasi permasalah ini setelah dilakukan obeservasi langsung dari tim kolaborasi pengabdian masyarakat disimpulkan untuk memanfaatkan alat bantu yang bersifat tekonologi tepat guna. Dengan perkembangan ilmu pengetahuan dan teknologi, khususnya dalam bidang pendidikan, penggunaan media pembelajaran semakin beragam dan iteraktif, salah satunya penggunaan media pembelajaran pada smartphone dalam bentuk aplikasi android. Sehingga para siswa didik dapat dengan mudah belajar melalui smartphone masing-masing, sedangkan materi yang disajikan dibuat menarik dan mudah untuk dimengerti.
Diharapkan dengan dibuat media pembelajaran tersebut alat bantu dapat digunakan secara maksimal, lebih efektif dan efisien serta mempermudah proses belajar siswa karena tidak hanya bisa belajar di sekolah melain bisa dimana saja dengan adanya media pembelajaran yang berbasis android ini.

\section{RUANG LINGKUP KEGIATAN}

Kegiatan pengabdian dipokuskan pada :

1. Materi Ilmu Batuan yang dipelajari nantinya adalah mengenai ganesa batuan, yang di dapat siswa didik kelas X Geologi Tambang SMK Negeri 1 Sendawar.

2. Media pembelajaran ini menampilkan gambar batuan yang akan dipelajari berdasarkan ganesanya dan karakteristik batuan tersebut.

3. Penyajian media pembelajaran ilmu batuan ini dalam bentuk aplikasi android dengan spesifikasi os android minimal versi 3.0 dan aplikasi ini tidak dilengkapi dengan fitur update. 


\section{BAHAN DAN METODE}

Adapun bahan dan metode yang digunakan dalam membangun aplikasi ini yaitu:

\subsection{Android}

Menurut Safaat (2012), android merupakan subset perangkat lunak untuk perangkat mobile yang meliputi sistem operasi, middleware dan aplikasi inti yang direlease oleh Google, sedangkan Android SDK (Software Devolopment Kit) Menyediakan tools dan API (Aplication Programing Interface) yang diperlukan untuk mengembangkan aplikasi pada platform Android dengan menggunakan bahasa pemrograman Java.

Dikembangkan bersama antara Google, HTC, Intel, Motorola, Qualcomm, T-Mobile, NVIDIA yang tergabung dalam OHA (Open Handset Alliance) dengan tujuan membuat sebuah standar terbuka untuk perangkat bergerak (mobile device).

\subsection{Eclipse}

Menurut Safaat (2012). Eclipse adalah sebuah IDE (Integrated Development Environment) untuk mengembangkan perangkat lunak dan dapat dijalankan di semua platform (platform-independent). Berikut ini adalah sifat dari Eclipse :

1. Multi-platform : Target sistem operasi Eclipse adalah Microsoft Windows, Linux, Solaris, AIX (Advanced Interactive Executive), HP-UX (Hewlett-Packard Unix) dan Mac OS X.

2. Multi-language : Eclipse dikembangkan dengan bahasa pemrograman Java, akan tetapi Eclipse mendukung pengembangan aplikasi berbasis bahasa pemrograman lainnya, seperti $\mathrm{C} / \mathrm{C}++$, Cobol, Pyton, Perl, PHP, dan lain sebagainya.

3. Multi-role : Selain sebagai IDF untuk pengembangan aplikasi, Eclipse pun bisa digunakan untuk aktivitas dalam siklus pengembangan perangkat lunak, seperti dokumentasi, test perangkat lunak, pengembangan web, dan lain sebagainya.

Eclipse pada saat ini merupakan salah satu IDE favorit dikarenakan gratis dan open source, yang berarti setiap orang boleh melihat kode pemrograman perangkat lunak ini. Selain itu, kelebihan dari Eclipse yang membuatnya populer adalah kemampuannya untuk dapat dikembangkan oleh pengguna dengan komponen yang dinamakan plug-in. Eclipse dibuat dari kerja sama antara perusahaan-perusahaan anggota "Eclipse Foundation" (beserta individu-individu lain). Banyak nama besar yang ikut dalam "Eclipse Foundation", termasuk IBM (International Business Machines), BFA (Bill ColemanEd Scott-Alfared Chuang), Intel, Nokia, Borland. Eclipse bersaing langsung dengan Netbeans IDE. Plugin tambahan pada Eclipse jauh lebih banyak dan bervariasi dibandingkan IDE lainnya.

\subsection{Swish Max4}

SwishMax merupakan sebuah program yang digunakan untuk membuat dan membangun sebuah animasi, movie atau film, banner, iklan, button navigasi atau presentasi, baik di dalam sebuah homeplage maupun berdiri sendiri. Swishmax merupakan program yang bersifat userfriendly dan banyak menarik kaum flasher dan web developer, karena Swishmax memiliki feature yang cukup lengkap untuk menghasilkan animasi yang menarik, baik animasi teks, image, grafik, suara, atau gabungan dari seluruh unsur media (Wisah, Ayu Ratih dan Gunawan, Hendra, 2010).

\subsection{Media Pembelajaran}

Menurut Warsita (2008), Media pembelajaran adalah usaha-usaha yang terencana dalam memanipulasi sumber-sumber belajar. Dalam pembelajaran terjadi peroses interaksi antara peserta didik pada suatu lingkungan belajar agar dapat belajar dengan baik.

Menurut Munir (2008), pembelajaran merupakan peroses pencarian ilmu pengetahuan secara aktif atau peroses perumusan ilmu, bukan peroses pengungkapan ilmu semata.

\subsection{Ilmu Batuan}

Batuan merupakan satuan pembentuk kulit Bumi atau Outer shell dari bumi, sementara mineral merupakan satuan pembentuk batuan. Kemungkinan $99 \%$ dari kulit Bumi terdiri atas 20 mineral utama dari ribuan mineral yang ada di Bumi. Keberadaan mineral Feldspar tidak hanya dominan dalam mineral Silikat, tetapi juga dominan sebagai mineral-mineral pembentuk batuan. Walaupun ada ratusan mineral tetapi hanya ada beberapa yang dijumpai mineral-mineral pembentuk batuan yang sebagian besar adalah pembentuk batuan beku dan batuan sedimen. Untuk batuan metamorf sendiri secara kimiawi sama dengan batuan beku dan sedimen.

\subsection{Tahapan Pengembangan Multimedia}

Menurut Binanto (2010), Metodologi pengembangan multimedia terdiri dari enam tahap, yaitu concept (pengonsepan), design (pendesainan), meterial collecting (pengumpulan materi), assembly (pembuatan), testing (pengujian), dan distribution (pendistribusian). Keenam tahap ini tidak dapat bertukar posisi. Meskipun begitu, tahap concept memang harus menjadi hal yang pertama kali dikerjakan.

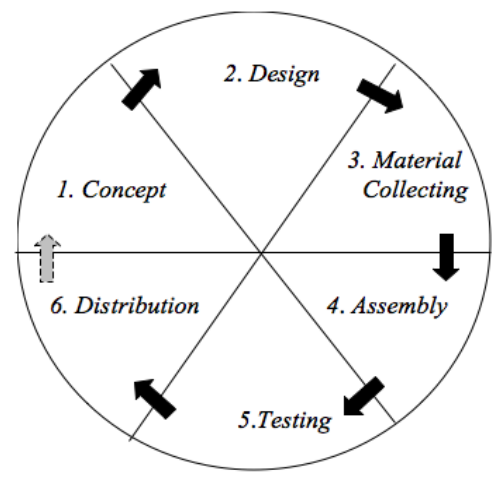

Gambar 1. Tahapan Pengembangan Multimedia 
Tahapan kegiatan pengabdian berupa tahapan pengembangan multimedia meliputi :

1. Concept

Tahap ini menentukan tujuan, termasuk identifikasi audiens, macam aplikasi (presentasi, interaktif, dan lainlain) dan spesifikasi umum, tujuan aplikasi (informasi, hiburan, pelatihan, dan lain-lain) dan spesifikasi umum. Dasar aturan untuk perancangan juga ditentukan pada tahap ini seperti ukuran aplikasi target, dan lain-lain.

2. Design

Membuat spesifiaksi secara rinci mengenai arsitektur proyek, gaya dan kebutuhan material untuk proyek. Spesifikasi dibuat cukup rinci sehingga pada tahap berikut, yaitu material collecting dan assembly tidak diperlukan keputusan baru, tetapi menggunakan apa yang sudah ditentukan pada tahap design.

\section{Material Collecting}

Material Collecting (pengumpulan bahan) dapat dikerjakan pararel dengan tahap assembly. Pada tahap ini dilakukan pengumpulan bahan seperti clipart image, audio, animasi, berikut pembuatan gambar grafik, foto, audio, dan lain-lain yang diperlukan untuk tahap berikutnya. Bahan yang diperlukan dalam multimedia dapat diperoleh dari sumber-sumber seperti perpustakaan, bahan yang sudah ada pada pihak lain atau pembuatan khusus yang dilakukan oleh pihak luar.

4. Assembly

Tahap assembly (pembuatan) merupakan tahap dimana seluruh objek multimedia dibuat. Pembuatan berdasarkan storyboard yang berasal dari tahap design. Pembuatan dilakukan dengan memasukan data yang digunakan untuk berbagai tampilan, serta cukup menemukan screen dengan urutannya.

\section{Testing}

Testing dilakukan setelah selesai tahap pembuatan dan seluruh data telah dimasukkan. Pertama-tama dilakukan testing secara modular untuk memastikan apakah hasilnya seperti yang diinginkan. Beberapa sistem mempunyai sistem mempunyai fitur yang dapat memberikan informasi bila terjadi kesalahan pada program.

\section{Distrution}

Bila aplikasi multimedia akan digunakan dengan mesin yang berbeda, penggandaan menggunakan flashdisc, DVD-ROM atau distribusi dengna jaringan sangat diperlukan. Suatu aplikasi biasanya memerlukan banyak file yang berbeda dan kadang-kadang mempunyai ukuran sangat besar. File akan lebih baik bila ditempatkan dalam media penyimpanan yang memadai.

\section{RANCANGAN SISTEM}

Perancangan aplikasi media pembelajaran ilmu batuan berbasis android ini menggunakan UML sebagai salah satu cara untuk mempermudah dalam pembuatan aplikasi ini.
Alur UML dimulai saat user membuka aplikasi dengan cara atau menekan icon "Belajar Batuan " dan sistem akan menampilkan menu utama dari media pembelajaran ilmu batuan ini. dapat dilihat bahwa pengguna sebagai siswa akan masuk pada tampilan awal menu terdapat 3 menu pilihan yaitu materi, kuis dan profil. Jika siswa menekan tombol materi maka akan masuk pada tampilan awal menu materi yaitu scene materi pengenalan ilmu batuan, selanjutnya jika user melanjutkan ke materi selanjutnya maka akan tampil scene pilihan materi belajar batuan yaitu ganesa batuan sedimen, ganesa batuan beku dan ganesa batuan metamorf. Jika user menekan tombol Ganesa Batuan Metamorf, akan tampil materi pembahasan tentang batuan metamorf jika telah memahami materi ini maka dapat melanjutkan ke materi selanjutnya yaitu tentang Batuan-Batuan Metamorf.

Pada scene Batuan-Batuan Metamorf terdapat dua page, page yang pertama berisi beberapa menu pilihan batuan seperti Slate, Serpetinit, Marmer, Hornfels, Filonit, tekan salah satu tombol pilihan batuan maka akan tampil deskripsi dari batuna tersebut. Sedangkan pada page 2 berisi menu pilihan batuan Gneiss, Milonit, Sekis, Kuarsit, Filit. Tekan salah satu tombol pilihan batuan maka akan tampil deskripsi dari batuan tersebut. Jika user menekan tombol Ganesa Batuan Beku maka akan tampil materi pembahasan tentang batuan beku, jika telah memahami materi ini maka dapat melanjutkan ke materi selanjutnya yaitu tentang Batuan-Batuan Beku. Pada scene batuan-batuan beku terdapat beberapa menu pilihan batuan yaitu Diorite, Dunite, Hornblende, Andesite, Granite dan Pumice. Tekan salah satu tombol pilihan batuan maka akan tampil deskripsi dari batuan tersebut. Jika user menekan tombol Ganesa Batuan Sedimen maka akan tampil materi pembahasan tentang batuan sedimen, jika terlah memahami materi ini maka dapat melanjutkan ke materi selanjutnya yaitu tentang Batuan-Batuan Sedimen.

Pada scene batuan-batuan sedimen terdapat beberapa menu pilihan batuan yaitu Gamping Berposil, Breksi, Rijang, Konglongmerat dan Gamping Kristalin. Tekan salah satu tombol pilihan batuan maka akan tampil deskripsi dari batuan tersebut. Jika user menekan tombol Kuis maka akan tampil scene kuis. Sebagai langkah awal kita mengisi nama terlebih dahulu lalu tekan tombol mulai, Tampilan soal terdiri dari angka $1-10$. Sistem akan secara acak mengeluarkan soal dengan bank soal yang tersedia ada 16 soal, setelah selesai sistem akan menampilkan nama dan nilai hasil dari kuis pengguna. Jika user menekan tombol menu Profil maka akan tampil scene profil dengan informasi sekilas tentang aplikasi media pembelajaran dan informasi mengenai pembuat aplikasi tersebut. 


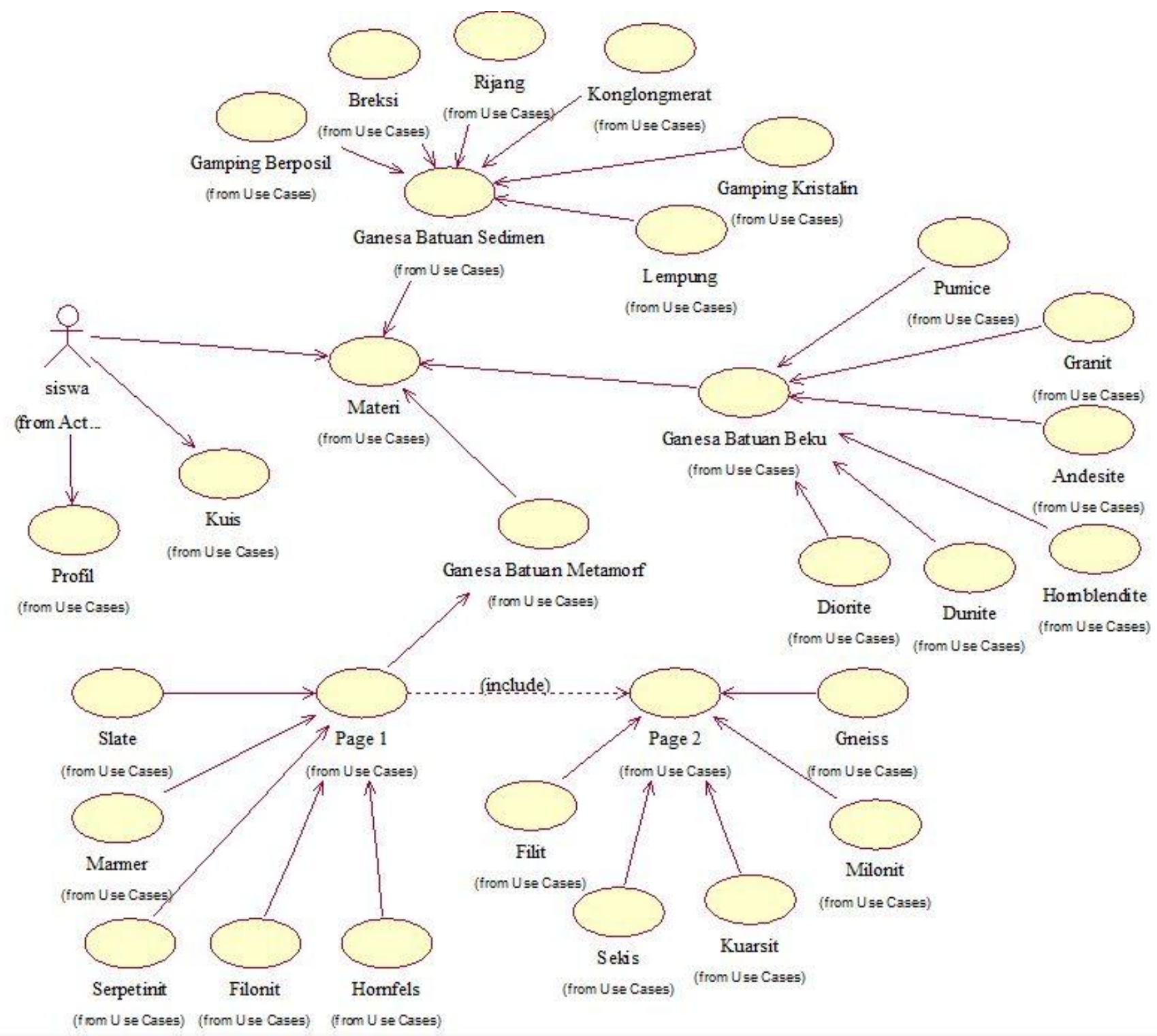

Gambar 2. Use Case Media Pembelajaran Ilmu Batuan Berbasis Android 


\section{IMPLEMENTASI}

Hasil implementasi berdasarkan analisis dan perancangan adalah sebagai beikut :

\section{Tampilan Menu Utama}

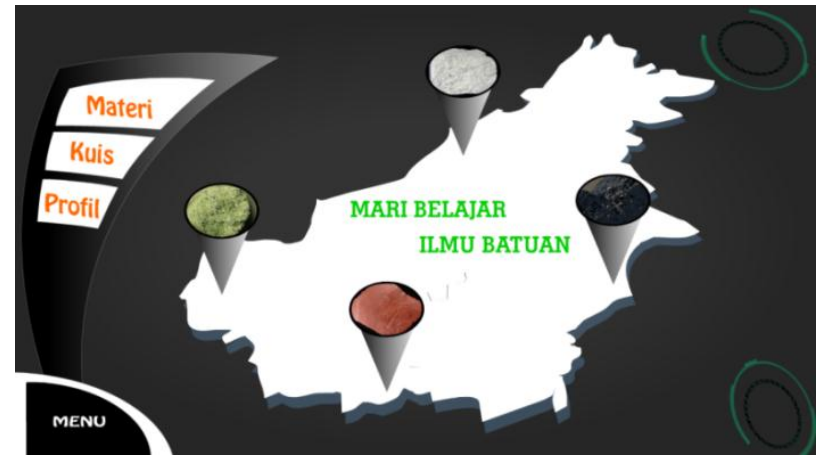

Gambar 3. Tampilan Menu Utama

Pada scene ini sistem akan memainkan musik "Parvus Decree 02 Digital Wind Ambient Mix" sebagai backsaound dari scene yang dimainkan. Jika user ingin mulai belajar, bisa dengan menekan tombol Materi maka user akan masuk pada scene pengenalan materi ilmu batuan. Jika user ingin menguji pengetahuan bisa dengan menekan tombol Kuis, maka akan masuk pada scene awal kuis. Jika user ingin melihat informasi mengenai aplikasi bisa dengan menekan tombol Profil.

\section{Scene Materi Pengenalan Batuan}

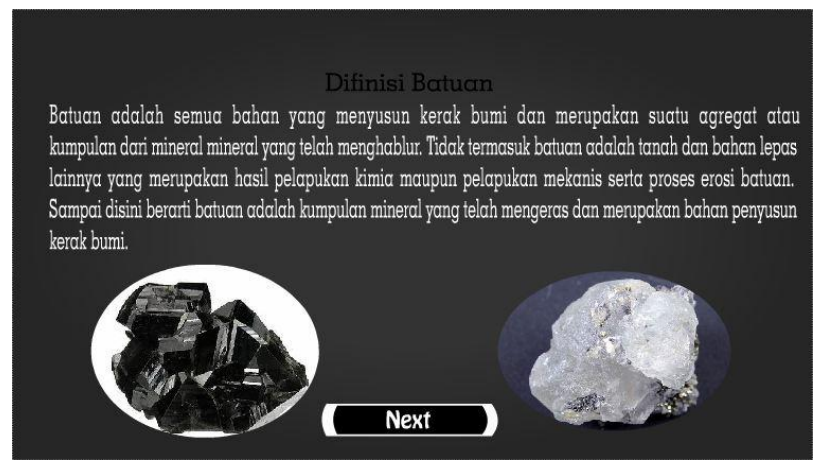

\section{Gambar 4. Tampilan Scene Materi Pengenalan} Batuan

Pada Scene Materi Pengenalan Batuan akan terdapat materi pengenalan kepada siswa yaitu tentang defenisi batuan, pada scene sistem akan memainkan musik "Parvus Decree 02 Digital Wind Ambient Mix" sebagai backsound dari scene. Setelah siswa mengerti tentang defenisi batuan dapat melanjutkan ke menu belajar selanjutnya dengan menekan tombol Next maka akan masuk pada scene materi pilihan ganesa batuan.
3. Scene Materi Pilihan Ganesa Batuan

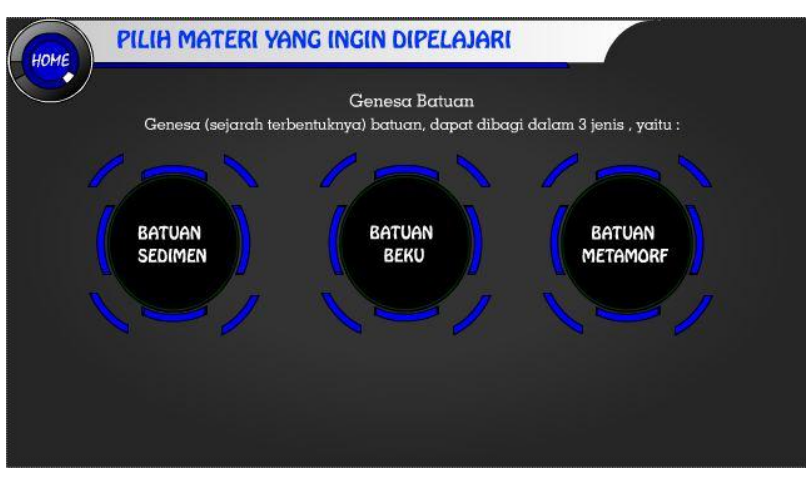

\section{Gambar 5. Tampilan Scene Materi Pilihan Ganesa Batuan}

Pada scene materi pilihan ganesa batuan (lihat gambar 4.3) ini menampilkan tombol materi ganesa batuan yaitu tombol batuan sedimen, batuan beku, batuan metamorf dan tombol home, pada scene ini sistem akan memainkan musik "Parvus Decree 02 Digital Wind Ambient Mix" sebagai backsound dari scene.

4. Scene Pembahasan Materi Batuan Sedimen

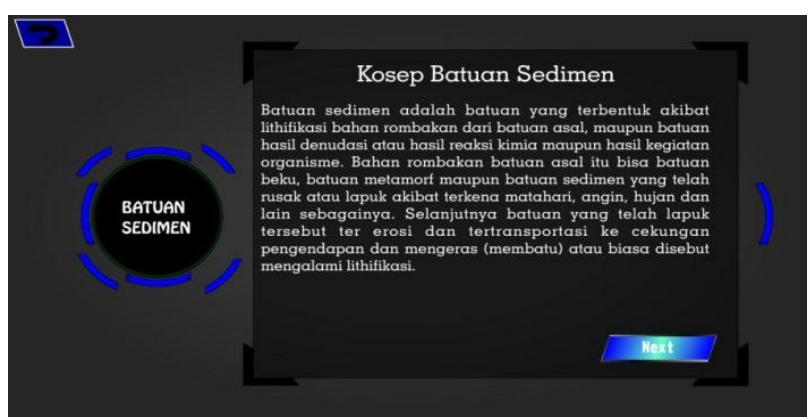

\section{Gambar 6. Tampilan Scene Materi Pilihan Ganesa Batuan}

Pada scene pembahasan materi batuan sedimen menampilkan 2 tombol yaitu back dan next. pada scene ini sistem akan memainkan musik "Parvus Decree 02 Digital Wind Ambient Mix" sebagai backsound dari scene. Pada scene ini akan menampilkan pembahasan materi mengenai batuan sedimen, yaitu proses yang terjadi sehingga terbentuknya batuan sedimen, jika user telah memahami materi pada bagian ini dan ingin melanjutkan pada materi berikutnya bisa dengan menakan tombol next maka akan menuju pada scene materi batuan-batuan sedimen dan jika ingin kembali pada scene materi pilihan ganesa batuan, tekan tombol back. 
5. Scene Materi Batuan-Batuan Sedimen

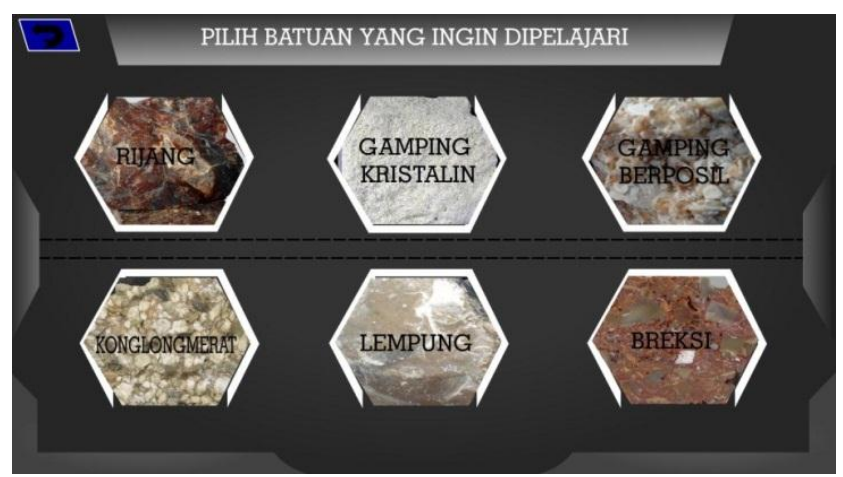

\section{Gambar 7. Tampilan Scene Materi Batuan-Batuan Sedimen}

Pada scene materi batuan-batuan sedimen menampilkan 7 tombol yaitu 6 tombol materi batuan sedimen "rijang, gamping kristalin, gamping berposil, konglongmerat, lempung, dan breksi" serta tombol back. pada scene ini sistem akan memainkan musik "Parvus Decree 02 Digital Wind Ambient Mix" sebagai backsound dari scene. Jika user ingin belajar mengenai batuan sedimen rijang bisa dengan menekan tombol rijang maka akan tampil scene deskripsi batuan-batuan sedimen rijang, begitu juga dengan materi lainnya. Jika ingin kembali pada scene pembahasan materi sebelumnya tekan tombol back.

\section{Scene Deskripsi Batuan-Batuan Sedimen}

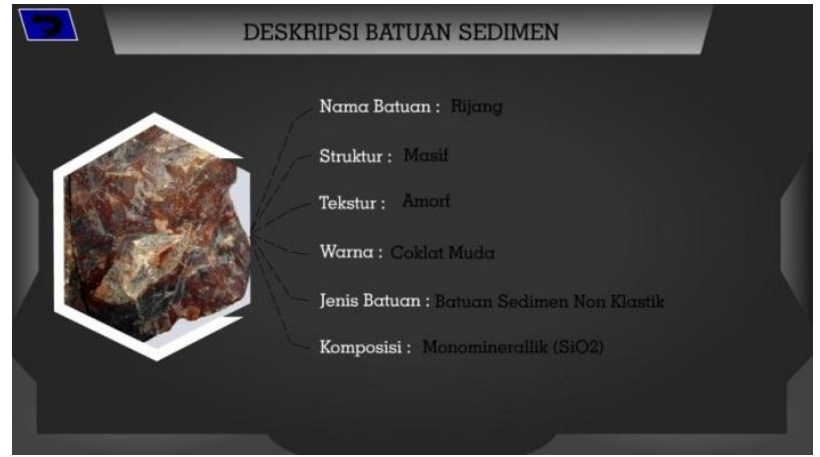

\section{Gambar 8. Tampilan Scene Deskripsi Batuan-Batuan} Sedimen

Pada scene deskripsi batuan-batuan sedimen (lihat gambar 4.6) akan menampilkan materi deskripsi dari batuan sedimen yang user ingin pelajari, contoh pada gambar 4.6 adalah deskripsi dari batuan sedimen rijang. Pada scene ini sistem akan memainkan musik "Parvus Decree 02 Digital Wind Ambient Mix" sebagai backsound dari scene. Deskripsi yang ditampilkan mulai dari nama batuan, struktur batuan, tekstur, warna, jenis batuan, dan komposisi dari batuan. Jika ingin pelajari batuan-batuan sedimen lainnya tekan tombol back maka akan kembali pada scene materi batuan-batuan sedimen.

7. Scene Pembahasan Materi Batuan Beku

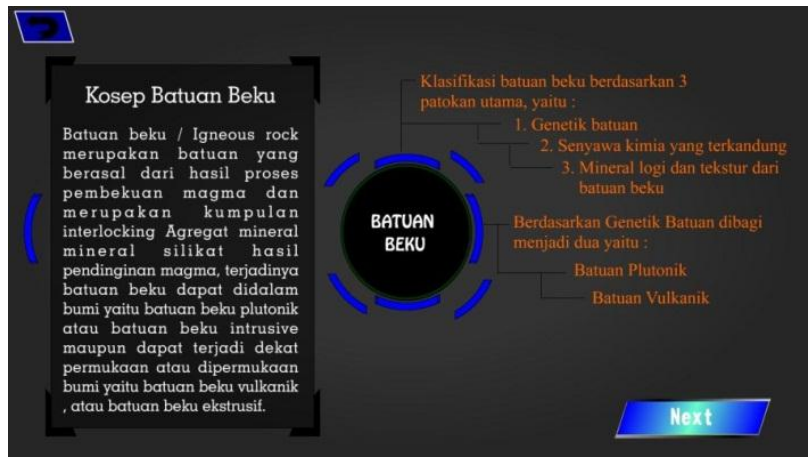

Gambar 9. Tampilan Scene Pembahasan Materi Batuan Beku

Pada scene pembahasan materi batuan beku (lihat gambar 4.7) akan menampilkan 2 tombol yaitu tombol back dan next. Pada scene ini sistem akan memainkan musik "Parvus Decree 02 Digital Wind Ambient Mix" sebagai backsound dari scene. Pembahasan materi yang ditampilakan pada scene ini mengenai konsep dari batuan beku yaitu proses dari pembentukan dari batuan tersebut. Jika user telah memahami materi pada bagian ini dan ingin melanjutkan pada materi berikutnya bisa dengan menakan tombol next maka akan menuju pada scene materi batuan-batuan beku dan jika ingin kembali pada scene materi pilihan ganesa batuan, tekan tombol back.

\section{Scene Materi Batuan-Batuan Beku}

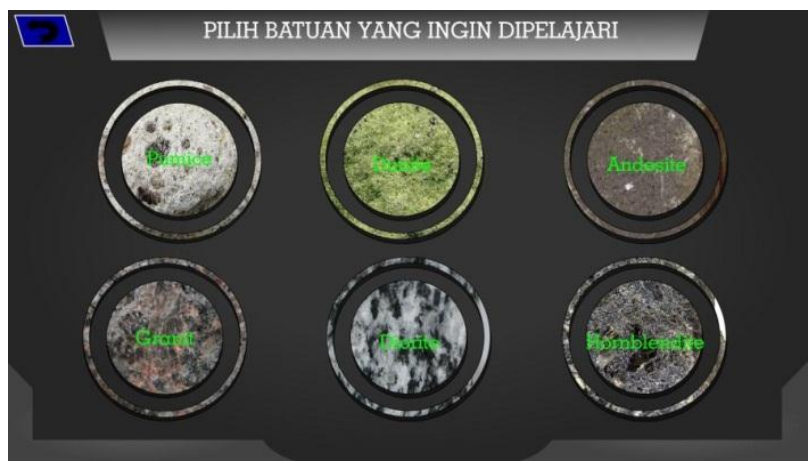

\section{Gambar 10. Tampilan Scene Materi Batuan-Batuan} Beku

Pada scene materi batuan-batuan beku akan menampilkan 7 tombol yaitu 6 tombol materi batuan 
beku "pumice, dunite, andesite, granite, diorit, dan hornblendite" serta tombol back. Pada scene ini sistem akan memainkan musik "Parvus Decree 02 Digital Wind Ambient Mix" sebagai backsound dari scene. Jika user ingin belajar mengenai batuan beku pumice bisa dengan menekan tombol pumice maka akan tampil scene deskripsi batuan-batuan beku pumice, begitu juga dengan materi lainnya. Jika ingin kembali pada scene pembahasan materi sebelumnya tekan tombol back.

\section{Scene Deskripsi Batuan-Batuan Beku}

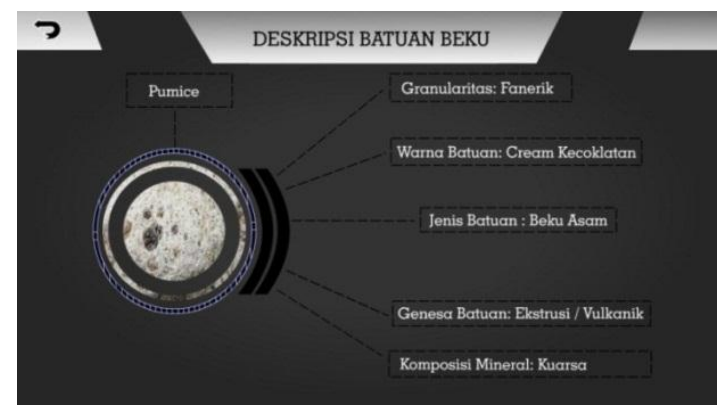

\section{Gambar 11. Tampilan Scene Deskripsi Batuan- Batuan Beku}

Pada scene deskripsi batuan-batuan beku (lihat gambar 4.9) akan menampilkan materi deskripsi dari batuan beku yang user ingin pelajari, contoh pada gambar 4.9 adalah deskripsi dari batuan beku pumice. Pada scene ini sistem akan memainkan musik "Parvus Decree 02 Digital Wind Ambient Mix" sebagai backsound dari scene. Deskripsi yang ditampilkan mulai dari nama batuan, granularitas, warna, jenis batuan, genetik batuan dan komposisi dari batuan. Jika ingin pelajari batuan-batuan beku lainnya tekan tombol back maka akan kembali pada scene materi batuan-batuan beku.

10. Scene Pembahasan Materi Batuan-Batuan Metamorf

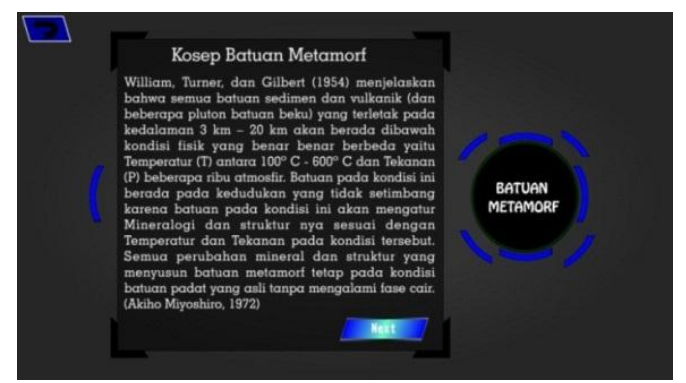

Gambar 12. Tampilan Scene Materi Batuan-Batuan Metamorf
Pada scene pembahasan materi batuan metamorf akan menampilkan 2 tombol yaitu tombol back dan next. Pada scene ini sistem akan memainkan musik "Parvus Decree 02 Digital Wind Ambient Mix" sebagai backsound dari scene. Pembahasan materi yang ditampilakan pada scene ini mengenai konsep dari batuan metamorf yaitu proses dari pembentukan dari batuan tersebut. Jika user ingin melanjutkan pada materi berikutnya bisa dengan menakan tombol next maka akan menuju pada scene materi batuan-batuan metamorf dan jika ingin kembali pada scene materi pilihan ganesa batuan, tekan tombol back.

\section{Scene Materi Batuan-Batuan Metamorf}

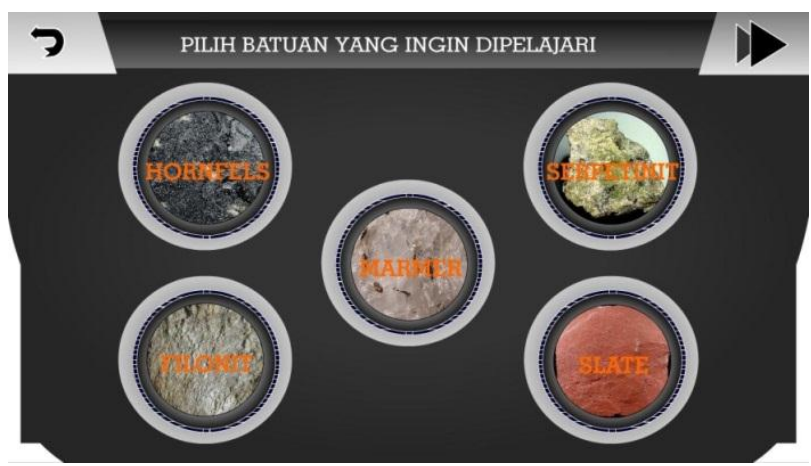

\section{Gambar 13. Tampilan Scene Materi Batuan-Batuan} Metamorf

Pada scene materi batuan-batuan metamorf (lihat gambar 4.11) akan menampilkan 7 tombol yaitu 5 tombol materi batuan metamorf "hornfels, filonit, marmer, serpetinit dan slate" serta tombol back dan next. Pada scene ini sistem akan memainkan musik "Parvus Decree 02 Digital Wind Ambient Mix" sebagai backsound dari scene. Jika user ingin belajar mengenai batuan metamorf marmer bisa dengan menekan tombol marmer maka akan tampil scene deskripsi batuan-batuan beku marmer, begitu juga dengan materi lainnya. Jika ingin kembali pada scene pembahasan materi sebelumnya tekan tombol back dan tekan tombol next jika user ingin melihat materi batuan-batuan metamorf lainnya. 
12. Scene Deskripsi Batuan-Batuan Metamorf

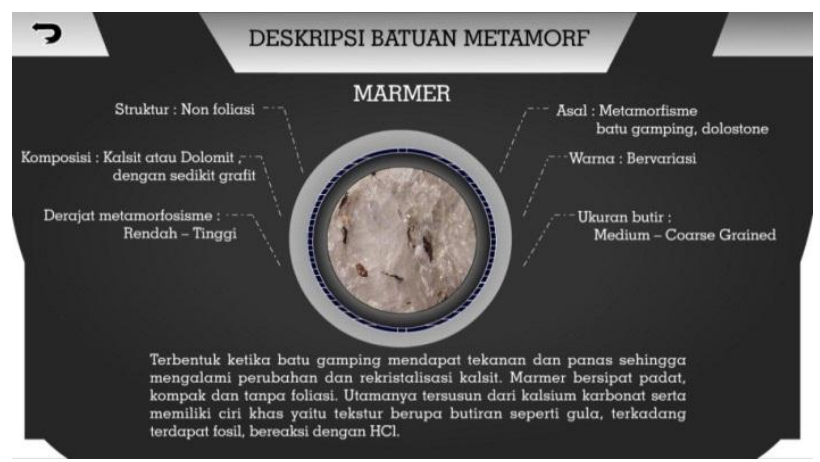

\section{Gambar 14. Tampilan Scene Deskripsi Batuan- Batuan Metamorf}

Pada scene deskripsi batuan-batuan metamorf akan menampilkan materi deskripsi dari batuan beku yang user ingin pelajari, contoh pada gambar 14 adalah deskripsi dari batuan metamorf marmer. Pada scene ini sistem akan memainkan musik "Parvus Decree 02 Digital Wind Ambient Mix" sebagai backsound dari scene. Deskripsi yang ditampilkan mulai dari nama batuan, struktur, komposisi, derajat metamorfosis, asal, warna, ukuran butir dari batuan dan penjelasan tentang batuan.

\section{Scene Kuis}

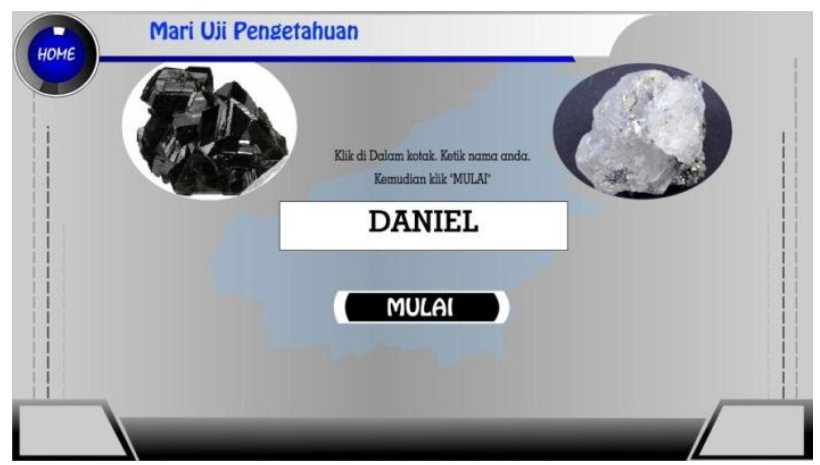

Gambar 15. Tampilan Scene Kuis

Pada scene kuis akan menampilkan tampilan awal sebelum user memulai kuis, ada 2 tombol pada scene kuis yaitu home dan mulai. Pada scene ini sistem akan memainkan musik "Parvus Decree 02 Digital Wind Ambient Mix" sebagai backsound dari scene. Jika ingin memulai kuis user harus terlebih dahulu mengisi nama pada kolom yang disediakan terlebih dahulu lalu tekan tombol mulai maka akan masuk pada soal-soal kuis yang telah disiapkan, dan ketika tombol mulai ditekan sistem akan secara otomatis mengacak urutan soal pada bank soal yang telah disediakan dan hanya menampilkan 10 soal untuk dikerjakan oleh user. Tekan tombol home jika user ingin kembali ke menu utama.

\section{Scene Soal Kuis}

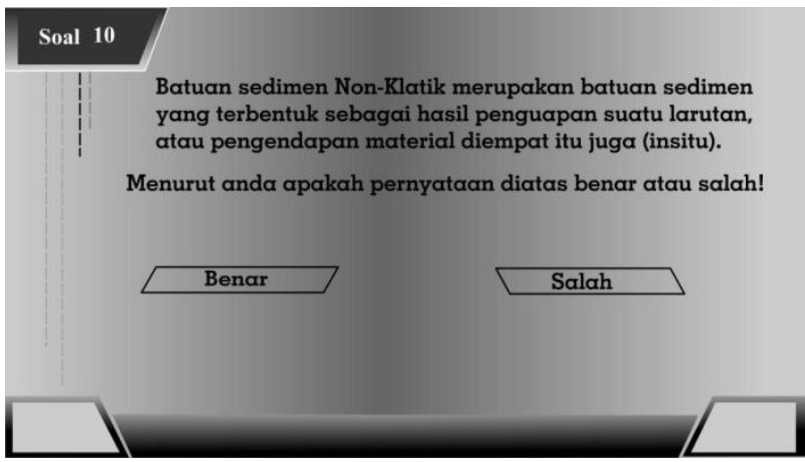

Gambar 16. Tampilan Scene Soal Kuis

Pada scene soal kuis pernyataan benar atau salah (lihat gambar 4.15) adalah salah satu contoh soal pernyataan benar atau salah yang akan dikerjakan oleh user. Jika menurut user pernyataan pada soal tersebut benar maka tekan tombol benar, karena soal yang dikerjakan hanya 10 soal maka setelah user menekan tombol benar sistem akan secara otomatis masuk pada scene nilai akhir kuis dan sistem akan menghitung hasil nilai yang diperoleh oleh $u$ ser.

\section{Scene Nilai Akhir Kuis}

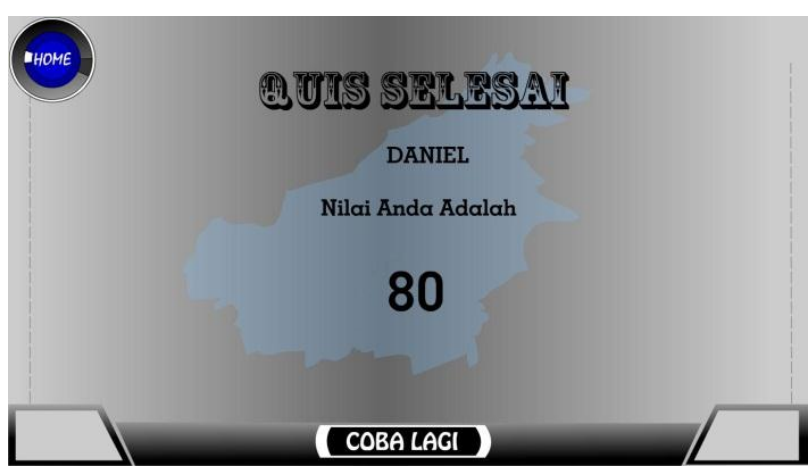

\section{Gambar 17. Tampilan Scene Nilai Akhir Kuis}

Pada scene nilai akhir kuis (lihat gambar 4.16) akan menampilkan nama dari user dan nilai yang diperoleh oleh user. Contoh pada gambar 4.16 sistem menampilkan nilai 80 dengan perhitungan rumus yang digunakan adalah ( Jawaban Benar x 10 = Nilai Akhir ). Pada scene ini sistem akan memainkan musik "Parvus Decree 02 Digital Wind Ambient Mix" sebagai backsound dari scene. 
Pada scene menu profil akan menampilkan profil dari pembuat aplikasi dan sekilas tentang aplikasi tersebut. Tekan tombol home jika ingin kembali ke menu utama.

\section{Distribusi Aplikasi}

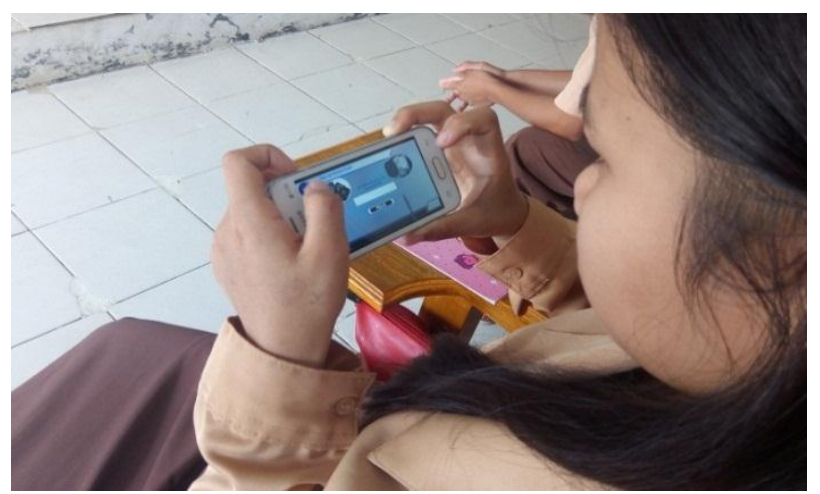

\section{Gambar 18. Seorang siswi sedang mencoba menu kuis pada aplikasi pembelajaran}

Pada tahap terakhir setelah implementasi aplikasi yaitu adalah tahap distribusi. Tahap ini juga merupakan tahap evaluasi terhadap suatu produk android, diharapkan akan dapat dikembangkan dalam bentuk yang lebih baik dikemudian hari.

\section{KESIMPULAN}

Hasil kegiatan pengabdian membangun alat bantu ajar berupa media pembelajaran ilmu batuan berbasis android pada SMK Negeri 1 Sendawar, menggunakan beberapa software yaitu SwishMax4 sebuah program yang digunakan untuk membuat dan membangun sebuah animasi, movie atau film, banner, iklan, button navigasi atau presentasi, baik di dalam sebuah homeplage maupun berdiri sendiri. dan Eclipse Indigo adalah alah satu software yang dapat anda gunakan untuk pembuatan aplikasi pada android dengan ekstensi apk. Metode pengembangan yang digunakan yaitu metode pengembangan multimedia yang diawali dengan concept, design, Material Colleting, assembly, testing dan distribution. Dengan adanya aplikasi berbasis android yang dapat memfasilitasi siswa dalam mempelajari ilmu batuan khususnya siswa jurusan geologi tambang yang belum memiliki dasar pengetahuan ilmu batuan.

\section{SARAN}

Berdasarkan hasil kegiatan pengabdian ini ada beberapa saran yang ingin disampaikan, yaitu sebagai berikut :

1. Untuk pengembangan aplikasi ini, diharapkan dapat lebih dikembangkan lagi secara materi maupun animasi agar lebih menarik dan sempurna, tidak hanya dapat dijalankan oleh 1 merk Smartphone saja namun juga dapat dijalankan dengan menggunakkan Smartphone lain.

2. Sebagai pengembangan aplikasi ini di harapkan konten atau materi pembelajaran pada aplikasi ini dapat di update secara berkala.

3. Untuk konten gambar diharapkan bisa dikembangkan lagi yaitu menampilkan bentuk tiga dimensi (3D) pada layar sehingga penyampaian materi menjadi lebih jelas.

4. Untuk bagian konten gambar diharapkan dapat di perbesar sehingga gambar dapat terlihat dengan jelas.

5. Untuk pendistribusian aplikasi yang lebih luas diharapkan aplikasi ini dapat di muat pada Play Store sehingga dapat dijangkau oleh pengguna lainnya.

\section{DAFTAR PUSTAKA}

Amin. M. Mustaghfirin. 2014. Batuan, Semester 1 Kelas 10. Jakarta : Kementrian Pendidikan dan Kebudayaan.

Amin. M. Mustaghfirin. 2014. Batuan, Semester 2 Kelas 10. Jakarta : Kementrian Pendidikan dan Kebudayaan.

Ariadi, Said. 2017. Edugame Pengenalan Bagian-Bagian Tubuh Manusia Dengan Tiga Bahasa Berbasis Android, Fakultas Informatika, Surakarta: Universitas Muhammadiyah Surakarta.

Binanto, Iwan. 2010. Multimedia Digital Dasar Teori + Pengembangan. Yogyakarta : Andi.

Fowler, Martin. 2005. UML Distiled. Yogyakarta : Andi. Munir. 2008. Kurikulum Berbasis Teknologi Informasi Dan Komunikasi. Bandung : Alfabeta.

Nugroho, A. 2005. Dasar-Dasar UML. Yogyakarta : Andi

Persius, Asi Melani. 2014. Membangun Permainan Mouse Hunter- Game Anti Korupsi Berbasis Android, Jurusan Teknik Informatika, Samarinda : Sekolah Tinggi Manajemen Informatika dan Komputer Widya Cipta Dharma.

Rumbaugh. 2006 UML Unifed Modeling Leanguge. Bandung : PT Graha Ilmu

Suyanto. 2007. Multimedia Alat Untuk Meningkatkan Keunggulan Bersaing. Yogyakarta: Andi.

Warista. 2008. Teknologi Pembelajaran. Jakarta : Rineka Cipta 